\title{
PHOTOGRAPHY AND EDUCATION: POSSIBILITIES FOR CHEMISTRY CLASSROOM
}

\author{
Tânia Cristina Vargas Sana \\ Colégio Saint Claire, São Paulo, Brazil \\ E-mail: vargastania@usp.br
}

\section{Dirceu Donizetti Dias}

E. E. Fernão Dias Paes, São Paulo, Brazil

E-mail: baumcima@yahoo.com.br

\author{
Agnaldo Arroio \\ University of São Paulo, Brazil \\ E-mail: agnaldoarroio@yahoo.com
}

\begin{abstract}
In today's world, students should not be disregarded as they have a direct and immediate relationship with new technologies, and an invasion of images is generally present in social life, and specifically in the classroom. These movements are argued in favour of more dynamic, interdisciplinary, contextualized activities and supported by the educational media. In this sense this paper aims to present and discuss a strategy that articulates the production of photo images during physical modelling of a scientific school apparatus named Daniell cell. Methodologically the photo images were analysed from an adapted taxonomy, complemented with semi-structured interviews and questionnaires. The results indicate that the proposed strategy improves the understanding of the subject content as well as the interest and motivation to work, however, also reveals the need to promote visual literacy in chemistry and natural science classes.
\end{abstract}

Keywords: chemistry education, images, photography.

\section{Introduction}

Considering the digital technology advances and also the easy access to the media, the need of the use of educational media in the process of teaching and learning is clear. The Science Education field has addressed the positive use of these tools in different visions, for example, the audio-visual products can be used to motivate students in the classroom, once the rhythm break is healthy by the fact to change the routine and allow the diversity of activities carried out (Arroio, 2010). In this same bias, it points out the use of images, especially the photo images, as a way of enhancing the teaching-learning process, since currently the use of digital photo images is facilitated, with the development of digital technologies and the costs of these devices. 
However, the invention of photography has allowed a gradual expansion to produce and use images, at the first moment in a selective and almost individual way, but later in a more massive way (Rodrigues, 2007). The possibility to work on the analysis of photo images is related to the junction of digital media in which images and habits are popularized, which leads to new needs of instruments for analysis (Ciacareli, 2011). Therefore, the photo image is understood as a sign that incorporates different codes and its reading demands the knowledge and understanding of these codes (Valle Gastaminza, 2001).

Historically the importance of using images in the learning process of the natural sciences has never been challenged, regardless of whether the images are part of a textbook, projected onto the wall of a classroom, or even in a screen as a video, because the focus used to increase the ability of observation for the mental construction of the studied phenomenon (Park; Slykhuis, 2006). In order to be effective, the images should provide information on the relationships between the concrete elements to be described in the text, improving their understanding. The effects on cognition with the use of images seem to be better when they provide a way for people to interpret what they have read or heard, that is, to help readers verify their understanding of the text by linking or organizing textual information (Bransford 1979, Ransford \& Johnson, 1972), in addition, the images act as facilitators in the retrieval of information in the long term (Findahl, 1981).

Levie and Lentz (1982) corroborating previous studies and after an extensive bibliographical review involving more than 50 studies investigating how the images affected the learning of information present in written texts, concluded that they provided irrefutable proof of the positive and significant effect of the images, both in terms of understanding and in terms of information retrieval. Levin (1989) summed up the essence of research results on the role of images in learning in this way: "Images interact with the text to produce levels of comprehension and memory that can exceed what the production of the text alone achieves" (1989, p. 89). In this same perspective an alert emerged in the study developed by Levin, Anglin and Carney (1987) in which they verified that the images that are fundamentally used as decorative elements do not have any positive effect and sometimes serve only as a distraction in relation to learning of the target concepts. Different learning methodologies contribute to the durability or fragility of memory. For example, comparisons of personal memories to words with their memories for photo images of the same objects show a superior effect when photographic images are used (Roediger, 1997).

According to this discussion photo images can be especially effective when students seek to show phenomena difficult to reproduce in non-specialized environments - such as organisms and microstructures, spatial relationships or even complex or dangerous chemical reactions. An interpretation of how images work was proposed by Paivio $(1971,1986)$, that suggests images are mediators of learning and may be surprisingly effective as memory aids due to the advantage of double coding, that is, the activation of memory and visual memory in working 
memory making it easier to connect the two codes and thus to remember and retrieve information. Images are indeed part of how we experience, learn, and know phenomena, as well as part of how we communicate and represent knowledge (Pink, 2013).

More specifically in the school context, the images can compose $50 \%$ of the content of educational books (Perales; Jiménez, 2002). It is necessary to consider the form and the method that these images are articulated with other representations, that is, the image alone is not enough, we must think on the way it is inserted in the communicative process. An image when used must be linked to a text, or any other narrative form, which associates, generates important information to the reader, producing effects that are linguistic and narrative and that often confuse with each other (Valle Gastaminza, 2001). In the perspective of Valle Gastaminza (2001) these effects can be understood as:

- The linguists that are the words, which point to information that the image is unable to bind, for example, when it serves as a guide for the reader to understand the meanings incorporated in the image.

Table 1. Example of linguistic effect.

\begin{tabular}{|c|l|}
\hline Image & \multicolumn{1}{c|}{ Comment } \\
\hline & $\begin{array}{l}\text { Example of linguistic effect, as there are words } \\
\text { that make explicit something that only with the } \\
\text { image would not be informed. (Image taken } \\
\text { from the textbook of Ricardo Feltre, p. 346 v. 2) }\end{array}$ \\
\hline
\end{tabular}

- The narratives that are the texts, which help the construction of the history recorded at that moment through a certain image, that is, the text contributes to reconstruct the universe represented in the photograph at that moment.

Table 2. Example of narrative effect.

\begin{tabular}{|l|l|}
\hline \multicolumn{1}{|c|}{ Image } & \multicolumn{1}{|c|}{ Comment } \\
\hline & $\begin{array}{l}\text { Example of narrative effect, as there is insertion } \\
\text { of information about the context of the image. } \\
\text { (Image taken from the textbook of Ricardo } \\
\text { Feltre, p. } 374 \text { v. 2) }\end{array}$ \\
\hline
\end{tabular}


The informative and documentary value of the text, by the narrative and linguistic effects is so important that it cannot be separated from the photo document and its presentation (Valle Gastaminza, 2001). In this study the images are treated as documentary photographs, since they will compose the students' report, they present other important characteristics, pointed out by Valle Gastaminza (2001) as attributes:

- Biographical attribute: which includes the photographic origin (when it was created, by whom and for what purpose);

- Thematic attribute: they understand the theme, aspects of denotation and connotation, that is, what appears in the photographic document and what it suggests.

Since it is very relevant what photo images show in the real sense and what people really understand, the denotative refer to what the image represents with - Relational attribute: understand the relationships that these documents establish with others. For example, the relationships established between the photo and the text corresponding to it. To construct, read and mainly understand different representations implies an important cognitive challenge, that demands to put into practice a series of operations of abstraction related mainly to the representation of space and the establishment of relations between the referent and the representative, that should allow the interpreter and whoever constructs the graphic information, reconstruct the meanings (Roldán, Vazquez, Rivarosa, 2009). In this sense the use of photo images brings the possibility to use these systems of expression, since it is a means that the individual has to externalize their mental representations (Duval, 2009), that is, it is an auxiliary mechanism by which students can complement the understanding of the thematic content written by the use of the graphical form.

In this context the meaning of a given representation is really important as the representation itself. For different people, the same representation can indicate different information and the socialization of these concepts can bring a good form of knowledge construction. The representation of an object or phenomenon is a construction that constitutes a model whose elements are selected according to a specific objective (Bruner, 1998) and in this perspective the external representation of a context contemplates three cognitive activities: the formation of representations, the treatment of representations and the conversion of the representations, being the three fundamental ones for the effective understanding of the studied content (Duval, 2009).

It is necessary in the moments of learning to introduce activities and bases that allow the conversion of representations, so that the subject coordinates the register and builds an integrated knowledge, thus dominating the different forms of external representation (Garcia, 2005). Recent literature on chemistry education field is concerned with how students move through different forms of representation, and many studies indicate that teachers should focus their attention on finding mechanisms that can help in this task (Dias, Weber, Arroio, 
2013). There is an incalculable number of images being produced today and made available to the public. The interest in images has led researchers from different fields as historians and educators to discuss more about images and the need for visual literacy (Sardelich, 2006). In this way: Do our students have the ability to work with different forms of representation? Are they able to move through the different forms of language, integrating images and textual narratives?

In this study the focus is on exploring how the photo images are integrated into the text, composing a particular semiotic system of representation and expression, which hypothetically stimulates interest in the object of the study, that is, how this dialogue is established and what are the relations between visual communication and textual communication. According to Valle Gastaminza (2001) and Perales \& Jiménez (2002), the explicit knowledge is valid only when there is a perfect integration between images and textual production of the student, that is, taking into account a series of particularities, the narrative text must be linked to the image to which it is associated.

\section{Methodology of Research}

The methodology employed was organized to start from the proposal of elaboration and manipulation of a school-scientific apparatus widely known in the high school like Daniell cell. Thirteen high school students, 16 years old, were subdivided into three collaborative work groups, which were instructed to record the entire elaboration and manipulation process of the Daniell cell by means of photo images. After completing the activities, the groups produced the experiment report (Dias \& Arroio, 2011), inserting the images obtained during the photo images registration of the activities. After the report the students were requested to answer a questionnaire using the scale like Likert between 0 and 10, where 0 corresponds to the lowest level of agreement to the statement and 10 to the highest level of agreement to the statement. The two statements referred to the degree of interest and the understanding about the content, from the insertion of photo image practice for registration for the final composition of the report. In addition, an interview was conducted with the students, in which their answers to the abovementioned questionnaire were asked, in order to have a better understanding how they conceive the use of photo images as a support strategy for the construction of knowledge. The analysis of the results was made in a first plane based on the taxonomy proposed by Perales and Jiménez (2002), discussed by Gibin, Kiill and Ferreira (2009) and adapted to this context (Table 3). 
Table 3. Taxonomy adapted for classification of photographic images.

\begin{tabular}{|c|c|c|}
\hline Category & Description & Subcategories \\
\hline Iconicity & $\begin{array}{l}\text { Degree } \\
\text { complexity } \\
\text { images. }\end{array}$ & $\begin{array}{l}\text { Photography - When the image is used for } \\
\text { interpretation of space and reality. } \\
\text { Figurative drawing with signs - Representing actions or } \\
\text { unobservable magnitudes in a space of heterogeneous } \\
\text { representation. }\end{array}$ \\
\hline Functionality & $\begin{array}{l}\text { What can be done } \\
\text { with the images. }\end{array}$ & $\begin{array}{l}\text { Inoperative - Does not indicate any usable element, it is only } \\
\text { for observation. } \\
\text { Elementary operations - Contain elements of } \\
\text { universal representation: sketches, dimensions, etc. } \\
\text { Syntactic - Contain elements whose use requires } \\
\text { knowledge of specific contents. }\end{array}$ \\
\hline $\begin{array}{l}\text { Relationship } \\
\text { with the text }\end{array}$ & $\begin{array}{l}\text { Mutual references } \\
\text { between the text } \\
\text { and image. }\end{array}$ & $\begin{array}{l}\text { Connotative - The text describes the content without } \\
\text { mentioning their correspondence with the elements } \\
\text { included in the illustration. These relationships are assumed } \\
\text { to be obvious, that is, relations that the own reader can do. } \\
\text { Denotative - The text establishes the correspondence } \\
\text { between the elements of the illustration and the contents } \\
\text { represented. } \\
\text { Synoptic - The text describes the correspondence } \\
\text { between the elements of the illustration and the contents } \\
\text { represented and also establishes the conditions in which } \\
\text { the relationships between the elements included in figure } \\
\text { represent the contents, so that the unity and the text form } \\
\text { an indivisible unity. }\end{array}$ \\
\hline Verbal tags & $\begin{array}{l}\text { Texts included in the } \\
\text { illustration. }\end{array}$ & $\begin{array}{l}\text { No label - The illustration does not contain any text. } \\
\text { Nominative - Letters or words that identify some elements } \\
\text { of the illustration. } \\
\text { Reliable - Texts that describe the relationships between the } \\
\text { elements of the illustration. }\end{array}$ \\
\hline
\end{tabular}

Source: Perales and Jiménez (2002)

At the same time, the results will be analysed by cognitive activities (DUVAL, 2009), which are related to the external representations that are: formation, treatment and the conversion of representations.

a) The formation of representation (identification of the represented object) is when it is sought that the student constructs the representation of a selected object or phenomenon. For example: the assembly of the Daniell cell.

b) The treatment of representation (it comprises a transformation of the registration representation within the same semiotic representation system in which it was formed) is when it is intended to broaden the representation of the object studied, but in the same semiotic system. For example: photographic production or figurative drawings with information of the requested phenomenon.

c) The conversion of representations (transformation of a given record of representation, belonging to a semiotic system in another register, belonging to 
another semiotic system), that is, when we try to transform the representation system into another. For example: relate the information of the images with the main text.

Also, consider the linguistic effects and attributes proposed by Valle Gastaminza (2001), the questionnaire responses according to the students' perspective, as to their positive or negative results, and finally, discuss the interviews.

\section{Results and Discussion}

The analysis was composed of three reports that presented a total of 16 images. Table 4 shows the percentage of the results in relation to the subdivisions of the categories presented in Table 1.

Table 4. Predominant percentages by analysis subcategory.

\begin{tabular}{|l|l|l|}
\hline \multicolumn{1}{|c|}{ Category } & \% (Subcategory predominant) & \multicolumn{1}{c|}{ Comment } \\
\hline Iconicity & $\begin{array}{l}94 \quad \text { (photography) Establish } \\
\text { photo is the lowest grade. }\end{array}$ & Establish photography is the lowest grade. \\
\hline Functionality & 56 (inoperative) & $\begin{array}{l}\text { The image does not point to any usable } \\
\text { element, it is only for observation. }\end{array}$ \\
\hline $\begin{array}{l}\text { Relationship with } \\
\text { text }\end{array}$ & 68 (connotative) & $\begin{array}{l}\text { The text describes the contents without } \\
\text { mentioning their correspondence with the } \\
\text { elements included in the photo. }\end{array}$ \\
\hline Verbal tags & 50 (absence of label) & The image does not contain any text. \\
\hline
\end{tabular}

Table 4 shows the synthesis of the data analysis indicating that in the category iconicity, $94 \%$ of the inserted images correspond to the photograph, which was to be expected, since it was the demand established by the teacher, however $6 \%$ of the images correspond to the iconicity figurative drawing with signs. In the functionality category $56 \%$ of the images are inoperative, that is, the photographic image fulfils only the illustration function, in which there is no addition of information and the inserted image becomes expendable. The remainder presents a syntactic characteristic, since it contains elements whose use requires the knowledge of specific standards, in this case the electrochemistry, and the information is treated in a superficial way, characterizing that it was produced for someone aware and understood of the concepts approached.

This fact reveals that students assume that these relationships are obvious, and that the reader can do them, assuming that this audience is the teacher. In the relation with the text, $68 \%$ of the images exhibit connotative properties, since the imagery registers do not communicate with the main text, which brings the discontinuity of the information. 
Finally, in the category verbal labels $50 \%$ of the images do not present texts or words that identify the imagery elements, that can make possible a better understanding of the concepts exposed. It is important to note that in the item iconicity, in addition to the photographic image, the students of a group also inserted a figurative drawing with signs, which leads one to believe, that they sought a more explanatory illustration and with more details, making the context more understandable, since according to Perales and Jiménez (2002), photo is the image of lesser degree of iconicity, that is, they require a greater knowledge of the symbolic code used.

For a better explanation of the categories studied, some examples from reports are presented by the students. In Table 5, we present the illustration presented by the students that represents the figurative drawing with signs.

Table 5. Representation of figurative drawing with signs.

\begin{tabular}{|c|c|}
\hline Images & Comment \\
\hline 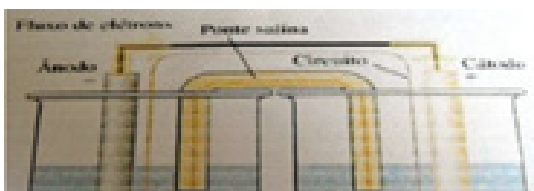 & $\begin{array}{l}\text { It is notable that this illustration has more } \\
\text { information than photography, as there are } \\
\text { indications of the materials, the substances } \\
\text { used and the oxidation equations involved in the } \\
\text { process. }\end{array}$ \\
\hline 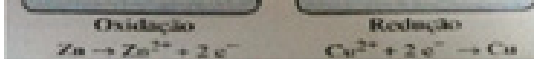 & \\
\hline
\end{tabular}

It is important to emphasize that in this image there is also the linguistic effect mentioned by Valle Gastaminza (2001), in which we find words that inform beyond the image, such as where the cathode and anode are in the oxidation-reduction process, information not explicit only in use of image.

Regarding functionality, which refers to the use of graphic tools as a way of expressing ideas, $56 \%$ of the images are inoperative, since they do not present concepts; they only fulfil the illustrative role. An example of this illustration is shown in Table 6.

Table 6. Example that characterizes an inoperative image.

\begin{tabular}{|l|l|}
\hline \multicolumn{1}{|c|}{ Image } & \multicolumn{1}{c|}{ Comment } \\
\hline & $\begin{array}{l}\text { This imaging content indicates that its use is } \\
\text { linked only to a decoration, as it does not refer } \\
\text { to more information. }\end{array}$ \\
\hline
\end{tabular}


In the category related to the text, $68 \%$ of the images exhibit connotative properties, that is, they appear isolated from the text, becoming discontinuous. The illustrations only gain meaning when the images are related to the written discourse, therefore the text must combine with the image so that it can contribute actively in the teaching-learning process (Perales and Jiménez, 2002). Such information reveals that students are not adequately literate to construct a dialogue between text and image. An example of this illustration is shown in Table 7.

Table 7. Example that characterizes a connotative image.

\begin{tabular}{|l|l|}
\hline \multicolumn{1}{|c|}{ Image } & \multicolumn{1}{c|}{ Comment } \\
\hline & $\begin{array}{l}\text { The photograph entered by the student is } \\
\text { not quoted in the main text, as well as what is } \\
\text { reported in the vicinity of the image is not in the } \\
\text { illustration. Therefore, there is no imaginary and } \\
\text { textual relationship. }\end{array}$ \\
\hline
\end{tabular}

As far as verbal labels are concerned, $50 \%$ of the photographic images do not present texts that identify the imagery elements, the other half was registered property, since there are texts or words referencing the illustrations. Perales and Jiménez (2002) maintain that these explanatory texts contained in the images favour the understanding and establish a better degree of knowledge of the studied content. It is necessary to clarify that in this category the text or words must be inserted in the figure, but since the proposal was the use of the photograph, any citation made close to the image was considered as a legend. Table 8 shows this type of classification.

Table 8. Example that characterizes a nominative image.

\begin{tabular}{|l|l|}
\hline \multicolumn{1}{|c|}{ Image } & \multicolumn{1}{|c|}{ Comment } \\
\hline & $\begin{array}{l}\text { For Perales and Jiménez (2002) the lower the } \\
\text { iconicity of an image, the greater the need } \\
\text { for explanation for its comprehension, so this } \\
\text { was not the result obtained by the students, } \\
\text { since almost all images were photographs (less } \\
\text { iconicity) and only 50\% of the illustrations had } \\
\text { some information. }\end{array}$ \\
\hline
\end{tabular}


In this context, the importance of textual information is better understood to better understand the elements that make up the image, and the photo caption plays an important role for photographic documentation (Valle Gastaminza, 2001). In this perspective, using the image / text relations of Valle Gastaminza (2001), 69\% of the images inserted in the reports produce narrative effects, that is, the text contributed to reconstruct the universe was represented in the photograph at that time. This demonstrates the importance of the student to be able to review the execution of the experiment in detail. This fact was also emphasized in the interview by some students.

A3: When we go to explain, it is very easy to have the photos of the moments, because we can remember everything we did.

The rest of the images produce linguistic effects, that is, words that point to information that the image alone is incapable of linking. For Perales and Jiménez (2002) the image is characterized by its polysemy, so that it is very difficult to predict the interpretation that a person will have this illustration. In this perspective the photographic image because it is ambiguous by nature, generating possibilities of different interpretations, when used in communication media, must be accompanied by titles, subtitles or some other type of identification (Rodrigues, 2007). In a paper by Leales and Lentz (1982) also emphasized by Perales and Jiménez (2002), which indicates the importance of the image / text, we observed that the most outstanding results for an effective learning process arise with: the valorisation of the introduction of images conveyed in the text; the relevance of the image when it generates text redundancy; and how the images provoke affective reactions making the content more attractive. Rodrigues (2007) states that, whatever the use of photo, the receptor, in interpreting it, will be influenced by their own mental images and by their entire cognitive, cultural and social context, and from this perspective the importance of the correct photographic reading, in which its interpretive text is essential for its clarification and so that there are no different translations among its recipients. In the photographic representation there are two realities created by Kossoy (2007) and discussed by Rodrigues (2007). The first refers to the referent itself, this is what was photographed and the second is the image produced, in this case the photograph of the first reality, and this first reality is subject to different interpretations. In the perspective of the external representation of Duval (2009), most of the students did not reach the three cognitive activities, since there was no conversion of the representations, that is, they could not relate the information of the images with the main text, which should have and the external representations (formation, treatment and conversion), since the passage from a natural language statement to a representation in another register requires a set of operations to name the objects. In the interview and in the questionnaire the students' responses to the use of photographic production were positive, they stand out as more motivating, and that, as it requires great attention during the construction process, generates a greater understanding of the content. 
A1: The photographic production left the experience much more interesting, because it was brought to the visual plane step by step, being able to show in detail to other people.

According to student A1 there is a concern to better expose the information, this makes it more attentive to the experiment, which facilitates the process of teaching-learning.

A2: Yes, because it leaves the work more active with photography, we had to be connected to the main moments.

Student $A 2$ addresses the need for attention to content for better display of results, thus enhancing understanding.

A1: The photos have encouraged a lot, as we can make content more realistic, more fun and increase the degree of learning.

Finally, it was noticed that there was greater interest in the use of photographic material, generating greater involvement and, consequently, a better result in the teaching and learning process.

\section{Final Considerations}

The students indicate that this process of literacy in the sphere of learning about chemistry / science increases the degree of interest and understanding of the thematic content, but at the same time express in their written communications a high degree of insufficiency in relation to the use of images. These data suggest that students present this difficulty due to non-literacy in imaging issues in the Chemistry / Sciences area and therefore do not develop the skills needed to understand and learn with images despite their massive presence in didactic materials. Due to the difficulties students present in translating information in different languages, teacher could organize activities in the classroom, in order to help students to overcome the superficial patterns of reading and interpretation, transposing them to levels that make it possible to establish relationships between founding, demonstrating and presupposing the phenomena represented. Through these results, it points out the great importance of using illustrations and codifications in the teaching of Chemistry / Sciences, as well as the possibility of transiting and interpreting different languages, for a better cognitive development, for the promotion of a critical citizen, active and evaluator of information. There is no doubt, that the world today is loaded with images and that photography, one of its greatest representatives, can help teachers to create better expectations in teaching - Chemistry / Science learning.

\section{Acknowledgment}

To the students participating in this research. 


\section{References}

Arroio, A. (2010). Context based learning: A role for cinema in science education. Science Education International, 21 (3), 131-143.

Bransford, J. D., Johnson, M. K. (1972). Contextual prerequisites for understanding: Some investigations of comprehension and recall. Journal of Verbal Learning and Verbal Behavior, 11 (6), 717-726.

Bransford, J. D. (1979). Human cognition: Learning, understanding, and remembering. Belmont, CA: Wadsworth Publishing Co.

Bruner, J. (1998). Acción, pensamiento y lenguaje [Action, thought and language]. Madrid: Alianza Editorial.

Ciacareli, N. (2011). A fotografia na sala de aula, a problemática da fonte imagética. Da efemeridade ao trabalho com a sensibilidade do olhar [The photograph in the classroom, the problematic of the imaginary source. From ephemerality to work with the sensitivity of the gaze]. In: III Encontro Nacional De Estudos Da Imagem. Londrina. Anais Fundação Araucária, p. 2246-2261.

Dias, D. D., Arroio, A. (2011). Aprendizagem Mediada por Gêneros do Discurso EscolarCientífico Projeto, Desenvolvimento e Utilização de Material Instrucional em Sala de Aula de Química [Gender-based learning of school-scientific discourse design, development, and use of instructional material in chemistry classroom]. Química Nova na Escola, 33 (2), 105-114.

Dias, D. D., Weber, K. C., Arroio, A. (2013). Construction of graphics in chemistry: An essential competence in investigative activities. Gamtamokslinis ugdymas / Natural Science Education, 38 (3), 7-20.

Duval, R. (2009). Semiósis e pensamento humano: registros semióticos e aprendizagens intelectuais. Coleção contexto da Ciência [Semósis and human thought: semiotic records and intellectual learning. Science context collection]. São Paulo: Livraria da Física.

Fernandes, H. L., Amâncio-Pereira, F. (2009). Imagens, ensino de ciências e tecnologias de informação e comunicação [Images, science teaching and information and communication technologies]. In: VII Encontro Nacional De Pesquisa Em Educação Em Ciencias. Florianópolis.

Findahl, O. (1981). The effect of visual illustrations upon perception and retention of new programmes. Communications, 7 (2-3), 151-168.

Garcia, J. J. G. (2005). La compressión de las representaciones gráficas cartesianas presentes en los libros de texto de ciencias experimentales, sus caracteristicas y el uso que se hace de ellas en el aula. $358 \mathrm{f}$. Tese (Doutorado) [The compression of the Cartesian graphical representations present in the textbooks of experimental sciences, their characteristics and the use that is made of them in the classroom] - Curso de Doutorado em Didática de Ciências Experimentais, Departamento de Ciências Experimentais da Faculdade de Ciências da Educação, Universidade de Granada, Granada.

Valle Gastaminza, F. (2001). El Análisis documental de la fotografía [The documentary analysis of photography]. 2001. Retrieved from: http://www.ucm.es/info/multidoc/ prof/fvalle/ArtCIIIWEB.htm.

Gibin, G. B., Kiill, K. B., Ferreira, L. H. (2009). Categorização das imagens referentes ao tema equilíbrio químico nos livros aprovados pelo PNLEM [Categorization of the images related to the subject of chemical equilibrium in the books approved by PNLEM]. Revista Electrónica de Enseñanza de las Ciencias, 8 (2), 711-721. 
Kossoy, B. (2007). Os tempos da fotografia [The times of photography]. São Paulo: Ateliê.

Levie, W. H., \& Lentz, R. (1982). Effects of text illustrations: A review of research. Educational Communication \& Technology Journal, 30 (4), 195-232.

Levin, J. R., Anglin, G. J., and Carney, R. N. (1987). On empirically validating functions of pictures in prose. In Willows, D. M., \& Houghton, H. A. (Eds.), The Psychology of Illustration: I. Basic research. Springer, New York, pp. 51-85.

Levin, J. R. (1989). A transfer-appropriate-processing perspective of pictures in prose. Knowledge Acquisition from Text and Pictures, 58, 83-100.

Melo, J. R. F. (2007). A formação inicial do professor de química e o uso das novas tecnologias para o ensino: um olhar através de suas necessidades formativas [The initial training of chemistry teachers and the use of new technologies for teaching: a look through their training needs]. 168 f. Dissertação (Mestrado em Ensino de Ciências Naturais e Matemática) - Universidade Federal do Rio Grande do Norte, Natal.

Paivio, A. (1971). Imagery and verbal processes. Oxford, England: Holt, Rinehart \& Winston.

Paivio, A. (1986). Mental representations: A dual-coding approach. New York: Oxford University Press.

Park, J. C., Slykhuis, D. A. (2006). Guest Editorial: Technology proficiencies in science teacher education. Contemporary Issues in Technology and Teacher Education, 6 (2), 218-229.

Perales, F. J., Jiménez, J. D. (2002). Las ilustraciones en La enseñanza aprendizaje de las ciencias. Análisis de los libros de texto [Illustrations in teaching science learning. Analysis of textbooks]. Enseñanza de lãs Ciencias, 20 (3), 369-383.

Pink, S. (2013). Doing visual ethnography. 3. ed. Australia: Sage Publications Ltda.

Rabello, E. T., Passos, J. S. (2013). Vygotsky e o desenvolvimento humano [Vygotsky and human development]. Retrieved from: http://www.josesilveira.com/artigos/ vygotsky.pdf.

Rodrigues, R. C. (2007). Análise e tematização da imagem fotográfica [Analysis and thematization of the photographic image]. Ciência da Informação, 36 (3), 67-76.

Roediger, H. L. (1997). Memory: Explicit and implicit. National Academy of Sciences, Washington, DC.

Roldán, C., Vázquez, A., Rivarisa, A. (2009). Las representaciones gráficas en tareas académicas universitarias. Enseñanza de las Ciencias, Número Extra, VIII Congreso Internacional sobre Investigación en Didáctica de las Ciencias, Barcelona, pp. 19191923. Retrieved from: https://ddd.uab.cat/pub/edlc/edlc_a2009nEXTRA/edlc_ a2009nExtrap1919.pdf.

Sardelich, M. E. (2006). Leitura de imagens e cultura visual: desenredando conceitos para a prática educativa [Reading of images and visual culture: unraveling concepts for educational practice]. Educar em Revista, 27 (2), 203-219.

Vygotsky, L. S. (2001). A Construção do Pensamento e Linguagem [The construction of thought and language]. São Paulo: Martins Fontes. 